24. Rathje S. Intercultural Competence: The Status and Future of a Controversial Concept. Language and Intercultural Communication. 2007. Vol. 7. № 4. P. 254-266.

25. Rogers E.M. Hall and The History of Intercultural Communication: The United States and Japan. Keio Communication Review, $2000 . \quad$ № $24 . \quad$ URL: www.mediacom.keio.ac.jp/publication/pdf2002/review24/2.

26. Rösch H. Mit Jim Knopf im heutigen China - Interkulturelle Kommunikation lehren an einer chinesischen Universität. Tourismus Journal. 2003. № 7. Heft 4. S. 523-542.

27. Samovar, L. Communication Between Cultures / L. Samovar, R. Porter, E. McDaniel, C. Roy. Belmont, 2013. $432 \mathrm{p}$.

28. Schumann A. Interkulturelle Kommunikation in der Hochschule: Zur Integration..., Bielefeld, transkript Verlag, 2012. $258 \mathrm{~s}$.

29. Spitzberg B. H., Changnon G. Conceptualizing Intercultural Competence. The SAGE Handbook of Intercultural Competence. Thousand Oaks, CA: Sage Publications, Inc., 2009. P. 1-51.

30. Thomas A. Interkultureller Austausch als interkulturelles Handeln. Theoretische Grundlagen d. Austauschforschung. Breitenbach, Saarbrücken 1985. $221 \mathrm{~s}$.

\title{
ОЛЬГА ПЕТРИШИНА
}

ID ORCID https://orcid.org/0000-0001-5427-200X petryshyna@tnpu.edu.ua кандидат філологічних наук, доцент

Тернопільський національний педагогічний університет імені Володимира Гнатюка вул. Максима Кривоноса, 2, м. Тернопіль

\section{ЛІНГВОДИДАКТИЧНІ ОСНОВИ ФОРМУВАННЯ НАВИЧОК ПУБЛІЧНОЇ КОМУНІКАЦЇ̈ У СТУДЕНТІВ НЕФІЛОЛОГІЧНИХ СПЕЦАЛЬНОСТЕЙ}

Формування комунікативної компетентності майбутніх учителів-нефілологів є пріоритетним завданням прогресивної освітньої парадигми. Нині в лінгводидактиці особливо актуалізується досконале володіння професійними комунікативними вміннями, майстерністю текстотворення в різних дискурсах. Врахування лінгводидактичних особливостей здобувачів вищої освіти лежить в основі формування навичок публічної комунікації, які корелюють із вимогами часу, потребами суспільства, завданнями сучасної освіти. Обтрунтування феномена «публічна комунікачія» з погляду лінгводидактики важливе для розробки методичних рекомендачій, концепчій та моделей навчання теорії $і$ практики публічной комунікачії, для підбору дієвих методів і прийомів. Публічна комунікачія особливо актуалізує значущі мисленнсво-мовленнєві операції: аналіз, синтез, абстрагування, порівняння тощо. Підходи до формування навичок публічної комунікації значною мірою опираються на відомі античні теорії $i$ практики, які потребують інноваційного методологічного і методичного опрацювання та проєктування на комунікативну компетентність сучасного вчителя-нефілолога. Характер мовної особистості визначається типовими комунікативними національними рисами, вираженими у вигляді мисленнєвих форм/формул, концептів, иіннісних лексико-семантичних домінант. Сучасний заклад вищої освіти (3ВО) прагне сформувати фахівия-оратора, готового до різних типів публічної комунікації, до творення будьякого дискурсу й адекватної моленннєвої поведінки в ньому, котрий володіє мовними нормами, комунікативними якостями усного і писемного мовлення, технологіями текстотворення, мовленнєвим етикетом. Вікові особливості, відкритість до сприйняття інформаиї̈, самовираження у конкурентних мовленнєвих ситуаціях, амбітність, пошук авторитетів, прагнення подолати стереотипи у сприйнятті професї вчителя - че ті лінгводидактичні аспекти, на які варто опиратися в роботі над комунікативною компетентністю здобувача.

Ключові слова: публічна комунікація, комунікативна компетентність, лінгводидактичні засади, студент-нефілолог.

\section{ОЛЬГА ПЕТРИШИНА}


Тернопольский национальный педагогический университет имени Владимира Гнатюка ул. Максима Кривоноса, 2, г. Тернополь

\title{
ЛИНГВОДИДАКТИЧЕСКИЕ ОСНОВЫ ФОРМИРОВАНИЯ НАВЫКОВ ПУБЛИЧНОЙ КОММУНИКАЦИИ У СТУДЕНТОВ НЕФИЛОЛОГИЧЕСКИХ СПЕЦИАЛЬНОСТЕЙ
}

\begin{abstract}
Формирование коммуникативной компетентности будущих учителей-нефилологов является приоритетной задачей прогрессивной образовательной парадигмы. Сейчас в лингводидактике особенно актуализируется владение профессиональными коммуникативными умениями, мастерством текстообразования в разных дискурсах. Учет лингводидактических особенностей соискателей высшего образования лежит в основе формирования навыков публичной коммуникации, которые коррелируют с требованиями времени, потребностями общества, задачами современного образования. Обоснование феномена «публичная коммуникация» с точки зрения лингводидактики важно для разработки методических рекомендаций, концепций и моделей обучения теории и практики публичной коммуникаиии, для подбора эффективных методов и приемов. Публичная коммуникачия особенно актуализирует значимые мыслительно-речевые операчии: анализ, синтез, абстрагирование, сравнение и др. Подходы к формированию навыков публичной коммуникации в значительной степени опираются на известные античные теории и практики, требующие инновационной методологической и методической обработки и проектирования на коммуникативную компетентность современного учителя-филолога. Характер языковой личности определяется типовыми коммуникачионными национальными чертами, выраженными в виде мыслительных форм/формул, концептов, иенностных лексико-семантических доминант. Современное УВО стремится сформировать специалиста-оратора, готового к различным типам публичной коммуникации, к созданию любого дискурса и адекватного речевого поведения в нем, обладающего языковыми нормами, коммуникативными качествами устной и письменной речи, технологиями текстообразования, речевым этикетом. Возрастные особенности, открытость к восприятию информации, самовыражение в конкурентных речевых ситуациях, амбициозность, поиск авторитетов, стремление преодолеть стереотипь в восприятии профессии учителя - это те лингводидактические аспекты, на которые следует опираться в работе над коммуникативной компетентностью соискателя.
\end{abstract}

Ключевые слова: публичная коммуникачия, лингводидактические основы, студент-нефилолог.

коммуникативная компетентность,

\section{OLGA PETRYSHYNA}

Candidate of Philological Sciences, Associate Professor Ternopil Volodymyr Hnatiuk National Pedagogical University

2 Maxym Kryvonis Str., Ternopil

\section{LINGUISTIC AND DIDACTIC FUNDAMENTALS OF DEVELOPING PUBLIC COMMUNICATION SKILLS OF STUDENTS MAJORING IN NON-LINGUISTIC SPECIALITIES}

Developing communicative competence of future teachers majoring in non-linguistic specialities is a priority of the progressive educational paradigm. Nowadays in linguodidactics the perfect mastery of professional communicative skills, the skill of text creation in different discourse conditions is especially relevant. Taking into account the linguistic and didactic characteristics of higher education seekers is the basis for the development of public communication skills that correlate with the requirements of the time, the needs of society, the tasks of modern education.

Substantiation of the phenomenon of "public communication" in terms of linguistic didactics is important for the development of guidelines, concepts and models for teaching the theory and practice of public communication, for the selection of effective methods and techniques. Speech is a necessary basis for thinking. Public communication especially foregrounds significant mental-speech operations: analysis, synthesis, abstraction, concretization, reproduction of material, text creation. The method of developing public communication skills focuses on solving problems related to the perception of educational material, awareness of the essence of rhetorical concepts, text creation. Effectiveness is ensured by synergy with psychological research on the patterns of mental operations that underlie the perception, memorization and reproduction of prepared material. Approaches to the development of public communication skills are largely based on wellknown ancient theories, including those based on folk speech culture. The analysis of the basic concepts of 
classical rhetoric and practice of public communication (logos, ethos, pathos and topos) require innovative methodological and methodical elaboration and directing at the communicative competence of the contemporary teacher majoring in non-linguistic specialities.

The character of the linguistic personality is determined by typical communicative national features, existing in the form of thought forms / formulas, concepts, value lexical and semantic dominants. The university should ideally mould a speaker ready for different types of public communication, to create a discourse in any time and space, who knows language norms and communicative qualities of oral and written speech as indicators of speech culture, text technology, speech etiquette. Age features, openness to the perception of information, self-expression in competitive speech situations, ambition, search for authority, the desire to overcome negative stereotypes in the perception of the teaching profession are the very linguistic and didactic aspects that should be relied on while working on communicative competence. We see the prospect of further research in the development of a system of work on the development of the idiosyncrasy of public communication which underlies the formation of a personal brand of the teacher.

Keywords: public communication, communicative competence, linguistic and didactic principles, nonphilologist student.

Початок XXI ст. характеризується бурхливим розвитком нових цифрових технологій, впровадженням їх в освітній процес, а відтак - зростанням ролі публічної комунікації, зорієнтованої на вироблення умінь і навичок продукування різних іiі жанрів з урахуванням психологічних, вікових і педагогічних особливостей мовників. Актуальною проблемою сьогодення $\epsilon$ прогресивна парадигма розвитку майбутніх учителів-нефілологів, які б досконало володіли професійними комунікаційними вміннями, майстерністю текстотворення в різних дискурсних умовах, знаннями й уміннями педагогічного красномовства. Формування навичок публічної комунікації може здійснюватися за умови врахування лінгводидактичних особливостей здобувачів освіти. Національна рамка кваліфікацій розглядає комунікацію і як важливу професійну компетентність, i як значущу прикладну навичку кожного кваліфікаційного рівня [4].

Упродовж останніх років вектор досліджень науковців із проблем формування публічної комунікації спрямований переважно на теоретичні лінгвістичні та комунікаційні розробки, тоді як педагогічно-психологічні аспекти переважно залишалися поза увагою. Проблеми монологічного, діалогічного і полілогічного мовлення як базових компонентів публічної комунікації студіювали лінгвісти Л. Мацько, М. Пентилюк, Г. Сагач та ін., лінгводидакти Н. Голуб, О. Горошкіна, Е. Палихата й ін. Відзначимо відомі дослідження про мовлення: як своєрідний вид діяльності (Л. Виготський, П. Гальперін та ін.), мовлення і його зв'язок $з$ мисленням (Г. Керт, О. Тихомиров та ін.), мовлення як діяльність, що характеризується певним мотивом i метою (В. Похилько, Б. Сосновський та ін.), і його емоційний компонент як природну потребу (М. Вітт, У. Грей, В. Шаховський та ін.).

Цікавими в цьому контексті є зарубіжні англомовні дослідження, які більше стосуються галузей психології, соціолінгвістики, теорії комунікації: 1) створення моделей і схем політичної і масової комунікації в галузі підсвідомості (Е. Берн, К. Юнг, 3. Фрейд та ін.), 2) психологічних феноменів впливу інформаційних повідомлень на свідомість слухачів з метою соціальної пропаганди комунікаційної політики (П. Лазерфельд, Г. Лассуел, Г. Олпорт, У. Шрамм та ін.). Ці та ряд інших дотичних досліджень дають розуміння часткових аспектів тлумачення, парадигматики, типології феномена «публічна комунікація». Однак проблеми формування публічної комунікації студентів педагогічних спеціальностей з урахуванням лінгводидактичних чинників не були предметом наукового дослідження і потребують поглибленого студіювання.

Актуальність дослідження зумовлена інтересом сучасної науки до риторичних і власне мовних явищ під час вивчення публічного мовлення, вимогами часу, потребами суспільства, завданнями сучасної освіти, що спонукають до створення психолого-педагогічного обгрунтування адаптації теорії публічної комунікації до освітнього процесу, осмислення сутнісної природи публічності та спеціальних методів і прийомів для заповнення важливої лінгводидактичної прогалини.

Метою статті $\epsilon$ висвітлення лінгводидактичних особливостей формування публічної комунікації як інструменту професійного та міжособистісного спілкування студентівнефілологів педагогічного ЗВО.

Поняття «комунікація» у перекладі 3 латинської означає «спілкуюсь із кимось», «спілкування, передача інформації» [7, с. 285]. Американський вчений Ф. Денс у праці з теорії 
комунікації ще в 1970 р. представив 120 визначень цього поняття [8, с. 201-210]. Закономірно, що відтоді науковий феномен зазнав багатьох інших фахових спроб тлумачення. Так, автори підручника 3 української мови за професійним спрямуванням для студентів-нефілологів інтерпретують комунікацію як «цілеспрямований інформаційний обмін в різноманітних процесах спілкування» [7, с. 143]. Певна непослідовність полягає в наведених тут міркуваннях: «поняття «комунікація» ширше поняття «спілкування», «ми розглядатимемо ці терміни як синоніми» [7, с. 143]. Поняття «публічний» у перекладі 3 латинської означає «суспільний, народний», такий, що «призначений для широкого користування, відвідування; громадський» [6, c. 474].

Отже, публічна комунікація є сутнісною характеристикою людського буття, принципом співіснування і взаємодії людей, засобом досягнення взаєморозуміння, при якій «єдність публічного простору - це не стільки єдність уявлень, скільки єдність відношень» [1, с. 76]. Відповідно до Програми 3 української мови (за професійним спрямуванням), «публічне монологічне мовлення є предметом дослідження риторики - теорії ораторського мистецтва, науки красномовства» [7, с. 180].

Як засвідчує практика, «публічне мовлення може відбуватися у різних формах, що володіють різними риторичними жанрами, - монологічними (жанри - промова, доповідь, проповідь, лекція тощо), діалогічними (інтерв'ю, бесіда, обговорення тощо) і полілогічними (дискусія, диспут, полеміка, дебати тощо)» [5, с. 18]. Відзначимо, що первинним у Стародавній Греції і Стародавньому Римі розвивалося і використовувалося переважно усне публічне монологічне мовлення: політичне (Демосфен, Сократ, Платон, Аристотель, Цицерон), судове (Емпедокл, Корак, Лісій, Горгій, Демосфен, Аристотель, Цицерон), моральне (Сократ, Платон), епідейктичне, тобто похвальне (Горгій («Похвала Олені», «Виправдання Паламеда»), Аристотель), військове (Тіртей, Гай Юлій Цезар), педагогічне (Гракх, Марк Фабій Квінтіліан), урочисте (Ісократ), хоча відоме й діалогічне публічне мовлення («Діалоги» Сократа, описані Платоном; діалоги Платона «Протагор», «Федр», «Софіст» та ін.).

Методика навчання українського публічного мовлення, як будь-яка інша, опирається на лінгвістику, в т. ч. психолінгвістику, і дидактику. Психологія як «наука про закономірності розвиток і форми психічної діяльності (психіки) живих істот ..., про особливості характеру, психіки» [6, с. 472] вивчає закономірності психіки, забезпечує взаємодію людей за допомогою мовлення, що, відповідно, вказує на використання людиною засобів мови, слова з метою спілкування. Мовлення - це форма існування мови у мовленнєвій діяльності, актах сприймання і розуміння під час слухання, актах говоріння і є результатом мовленнєвої діяльності [3, с. 39]. Відповідно, мовленнєва діяльність $є$ мовленнєвою поведінкою людини, опосередкованою знаками мови. У цій діяльності жваво співпрацюють свідомість, воля, мислення, активізовані комунікаційною метою висловлювання. Єдність мови, мовлення і мислення, їхня взаємозалежність не означає їх тотожності та ідентичності. Мисленнєвий аспект мовленнєвого висловлювання в комунікації - це «головним чином відтворення фіксованої мовою картини світу. Мова пов'язана 3 мисленням не безпосередньо, а лише через предмети і явища дійсності» [5, с. 16].

Мовлення $є$ необхідною основою мислення під час вираження власних думок, оскільки думка не може виникнути та існувати поза мисленням. Перш ніж висловити думку, мовець спрямовує свідомість до свого наміру, до власного задуму, тобто враховує мовленнєву інтенцію - бажання виразити свої думки і переконання. Методика формування публічної комунікації зосереджує свою увагу на розв'язанні завдань, пов'язаних зі сприйманням навчального матеріалу, усвідомленням сутності риторичних понять, що забезпечується психологічними дослідженнями про закономірності мисленнєвих операцій, які знаходяться в основі сприймання, запам'ятовування і відтворення підготовленого матеріалу. Сутність психологічних процесів використовується під час створення і розробки методичних рекомендацій, концепцій i моделей навчання комунікативності, забезпечується функціонуванням методів і прийомів, засадничих для мовленнєво-мисленнєвої діяльності: аналізу, синтезу, абстрагування, конкретизації, відтворення матеріалу, створенням текстів тощо. Власне, психолінгвістика засвідчує взаємозв'язок мовлення і мислення, вплив мовлення на психічний розвиток молодої людини i, навпаки, ii психічного стану на мовлення, формування мовно-мовленнєвої свідомості, діяльність мовленнєвої особистості 3 національною специфікою мовленнєвої поведінки і соціального символізму як основного прийому відображення дійсності. 
Аналіз основних понять класичної риторики і водночас практика публічної комунікації (логос, етос, пафос, топос) засвідчують: зв'язок мовлення і мислення найбільше відображає поняття «логос», що означає «а) слово, мова, мовлення і б) поняття, думка, розум, а точніше єдність цих понять» [2, с. 10] і стосується сфер логіки.

Зв'язок мови, мовлення, лінгвістики, психолінгвістики, дидактики вбачаємо передусім в інтенції - першому розділі класичної риторики, «в якому розробляється етап задуму, намірів, ідей, формулювання гіпотези майбутнього виступу» [2, с. 14], систематизуються знання про предмет мовлення, зіставляються 3 іншими знаннями за допомогою різних видів пам'яті $\mathrm{i}$ мислення. Аналогічні зв'язки використовуються в диспозиції, що пропонує логічні операції на етапі побудови публічного тексту, завдяки яким знімається суперечливість визначень. Наступним кроком при запам'ятовуванні змісту публічного висловлювання $є$ меморія, що пояснюється як запам'ятовування підготовленого виступу, багаторазове повторення i використовується, «щоб не розгубити не тільки фактичну інформацію, але й образність, цікаві деталі» [2, с. 15].

Зупинимося на теорії монологу, будуючи який відомі античні автори опиралися на фольклорну мовленнєву культуру. Звідси виникли дві системи понять риторики: система понять Аристотеля (Греція), що відображає переважно систему понять для слухача і мовця, $\mathrm{i}$ система понять Квінтіліана (Рим), що демонструє правила для мовця. Обидві системи послужили основою навчання і виховання ораторів.

Методика навчання будь-якого предмета $є$ наукою педагогічною, що має інтегрований характер, позаяк вона опирається на низку інших наук, зокрема на педагогіку - теорію освіти та навчання (дидактика) і теорію виховання. Думки про навчання висловлювали у Стародавньому світі видатні філософи Сократ, Демокріт, Геракліт, Платон, Аристотель та ін., а про навчання риторики, красномовства, а отже, і публічного мовлення - учителі-софісти, Аристотель, Платон, Квінтіліан, які створювали свої риторичні школи. Отже, шкільна риторика стає основою античної освіти 3 обов'язковою декламацією вигаданих промов політичних (суазорій) і судових (контраверсій).

Теорія освіти і навчання висвітлює закономірності діяльності викладача та здобувача у 3ВО, визначає і характеризує сутність, принципи, зміст, методи й організацію освітнього процесу. Під час формування умінь і навичок публічної комунікації на заняттях із риторики та публічної комунікації конкретизуються загальнодидактичні принципи (науковості, систематичності і послідовності, свідомості й активності, наочності, грунтовності тощо) як вихідні положення теорії навчання.

Так, дотримування принципу наочності у методиці вивчення риторики загалом i публічного мовлення зокрема вимагає:

1) методичного осмислення використання на заняттях традиційної наочності, оформленої у таблицях, схемах;

2) використання наочних засобів, які демонструють у тій чи іншій формі моделі мовленнєвої поведінки (малюнки, ілюстрації, репродукції);

3) добирання і створення аудіо- і відеоматеріалів, які демонструють моделі мовленнєвої поведінки у різних ситуаціях публічної комунікації;

4) створення презентацій для демонстрування нових форм і моделей спілкування, пов'язаних з освоєнням нових засобів інформації.

У методиці навчання риторики, публічної комунікації використовуються відомі методи для ознайомлення 3 теоретичним матеріалом i його практичним застосуванням. До них належать комунікаційні методи навчання всіх форм публічної комунікації: монологічної (методрозповіді, методпояснення, методінформування, міні-лекція, вступне чи завершальне слово викладача як метод тощо), діалогічної (метод бесіди (фронтальна, евристична, завершальна), метод інтерв'ю, метод обговорення тощо), полілогічної (методи: дискусії, диспуту, полеміки, дебатів тощо), а також практичних методів, серед яких - метод вправ. У сучасній лінгводидактиці розроблено класифікації методів, що доповнюються новими різновидами і підходами стосовно навчання публічного мовлення, а саме: демонстрація (показ), організація вправляння, риторичний аналіз, риторичне завдання тощо.

Важливо пам'ятати, що суб'єкта публічної комунікації інтерпретують 3 погляду національної специфіки, який володіє культурно зумовленими ментальністю, картиною світу, 
системою цінностей, дотримується стереотипних етнокультурних підходів у текстотворенні, поведінкових, мовних, комунікативних норм. Характер публічної комунікаційної мовної особистості визначається типовими психоемоційними національними рисами, вираженими у вигляді мисленнєвих форм/формул, концептів, ціннісних лексико-семантичних домінант. Мовна особистість як центральна в публічній комунікації - це єдність колективного та індивідуального, що існує в нерозривному зв'язку. У цьому разі ми говоримо про образ оратора, готового до різних типів публічної комунікації, продукування текстів, до творення дискурсу в будь-якому часопросторі, який володіє мовними нормами, комунікативними якостями усного і писемного мовлення як показниками мовленнєвої культури, технологіями текстотворення, мовленнєвим етикетом і відповідними засобами - паралінгвістичними та логіко-емоційної виразності.

У типовій програмі дисципліни «Українська мова (за професійним спрямуванням)» й укладеному до неї підручнику, затверджених $\mathrm{MOH}$ України, визначено теоретичний i практичний матеріал про спілкування як інструмент професійної діяльності та риторику, який студенти-нефілологи мають засвоїти (з-поміж іншого, відзначимо теми «Спілкування як інструмент професійної діяльності», «Гендерні аспекти спілкування», «Публічний виступ як важливий засіб комунікації», «Мистецтво аргументації», «Презентація як різновид публічного мовлення», «Культура сприймання публічного мовлення», «Уміння ставити запитання i слухати» й ін. [6, с. 594]. Водночас передбачено формування навичок діалогічного та полілогічного мовлення (наприклад, «Індивідуальні та колективні форми фахового спілкування», «Стратегії поведінки під час ділової бесіди», «Мистецтво перемовин», «Збори як форма прийняття колективного рішення» тощо) [6, с. 594-595]. Взаємодія зі студентаминефілологами, особливо в умовах дистанційного, змішаного навчання під час карантинних обмежень, засвідчує труднощі у формуванні навичок публічної діалогічної та полілогічної комунікацій.

Для розвитку діалогічної публічної комунікації пропонуємо ознайомитися з теоретичним матеріалом про діалог, діалогічне мовлення, діалогічне спілкування, діалогічний текст, діалогічні єдності, діалогічні репліки, їхню класифікацію; жанри публічної діалогічної комунікації (бесіду, розмову, інтерв'ю, обговорення, суперечку тощо), приблизну, а не точну їхню структуру, позаяк усний діалог є спонтанним, тому не завжди продуманим, керованим, вимагає серйозних фахових компетентностей, креативності, мовленнєвої організованості.

Полілог - це форма спілкування, в якій бере участь кілька осіб, мовлення яких складається 3 діалогічних єдностей і реплік. Відмінними від діалогічного мовлення $є$ лише жанри полілогічного публічного мовлення - дискусія, диспут, полеміка, дебати тощо, які теж мають бути у радіусі формування усієї публічної комунікації: монологічної, діалогічної і полілогічної. У цьому разі і вправи для виконання в аудиторії чи в позааудиторний час матимуть свою класифікацію і будуть спрямовані на вироблення умінь і навичок продукування не тільки монологічної публічної комунікації, а й діалогічної та полілогічної.

Практична робота над формуванням діалогічної і полілогічної публічної комунікації має розпочинатися 3 тренування студентів у продукуванні діалогічних реплік і діалогічних єдностей тематичного спрямування, що можуть використовуватися для побудови діалогічних і полілогічних текстів. Насамперед студенти повинні володіти проблемою, якій буде присвячений діалог чи полілог, дискурсом, темою спілкування. Варто враховувати психологічні та вікові особливості студентів (максималізм, відстоювання власної позиції, амбітність, прагнення до самоствердження i самовираження в колективі, інтенція до оригінальності тощо), методичну підготовку викладача до формування цієї форми публічної комунікації.

Ця робота передбачає попереднє вивчення і збагачення словникового запасу студентів із проблеми, яка буде предметом діалогічного чи полілогічного спілкування, спрямованого на досягнення комунікативної мети, поставленої перед мовцями. Навчальний діалог чи полілог спочатку модерується викладачем, згодом студенти працюють самостійно, опираючись на тему або ситуацію (природну чи змодельовану).

Не обмежуючись темою комунікації, пропонуємо практичні завдання з публічної комунікації, які можуть мати такий алгоритм: 
1. Ознайомитись із лексиконом, потрібним для спілкування в діалозі чи полілозі, для досягнення комунікативної мети.

2. Користуючись матеріалами підручників про дотримання культури мовлення $\mathrm{i}$ мовленнєвого етикету, виробити правила мовленнєвого етикету під час діалогічного чи полілогічного спілкування.

3. Побудувати: a) репліки-стимули для початку і подальшого підтримування процесу діалогування; б) репліки-реакції на запропоновані репліки-стимули з певної теми; в) реакційностимулювальні репліки для продовження комунікації.

4. Створити: а) репліки-стимули для початку полілогічного спілкування, вибрати найбільш доречні, навчитися їх виголошувати, аргументуючи висловлену тезу; б) реплікиреакції для продовження спілкування, згоди чи заперечення почутого, доведення правильності чи неправильності суджень одного чи декількох співрозмовників.

5. Підготувати план проведення дискусії (диспуту, полеміки, дебатів), врахувати ситуацію проведення полілогу, учасників, їхню мовленнєву, культуромовну й етикетну готовність, врахувати дискурсну специфіку (ймовірні висловлювання, поведінку співрозмовників тощо).

6. Провести публічну дискусію чи іншу форму полілогу перед невеликою аудиторією, після чого виявити помилки і недоречності.

7. Провести дискусію чи диспут перед великою аудиторією, долучити студентів до полеміки чи дебатів із запропонованої викладачем проблеми.

Здобувачі освіти активно долучаються до таких форм роботи, непомітно для себе виробляють навички публічної комунікації. Фаховий дискурс, що студенти-нефілологи самі ж і творять, стає природним освітнім середовищем, в якому відбувається їхнє професійне становлення.

Отже, формування навичок публічної комунікації студентів-нефілологів має конкретні психолого-педагогічні передумови і вимагає знань багатьох суміжних і недотичних наук. Вікові особливості, відкритість до сприймання різнотипної інформації, самовираження i самоствердження в конкретній мовленнєвій ситуації, амбітність, пошук авторитетів (у т. ч. комунікативних), прагнення подолати негативні стереотипи у сприйнятті професії вчителя - це ті психолого-педагогічні аспекти, на які варто опиратися в роботі над комунікативною компетентністю здобувача.

Перспективу наших досліджень вбачаємо у розробці системи роботи над формуванням індивідуальної манери публічної комунікації (ідіостилю) майбутнього педагога, яка лежить в основі формування його особистого бренду.

\section{ЛІТЕРАТУРА}

1. Арендт X. Vita Activia или о деятельной жизни. СПб.: Алетейя, 2000. 437 с.

2. Мацько Л. І., Мацько О. М. Риторика: навч. посібник. К.: Вища школа, 2003. 311 с.

3. Методика викладання української мови в середній школі: навч. посіб. / за ред. І. С. Олійника. 2-ге вид., перероб. і доп. К.: Вища школа, 1989. 439 с.

4. Національна рамка кваліфікацій. URL: https://zakon.rada.gov.ua/laws/show/1341-2011$\% \mathrm{D} 0 \% \mathrm{BF} / \mathrm{paran} 12 \# \mathrm{n} 12$

5. Палихата Е. Я. Система навчання українського усного діалогічного мовлення учнів основної школи: дис. ... д-ра пед. наук: 13.00.02. К., 2005. 36 с.

6. Словник іншомовних слів / уклад. С. М. Морозов, Л. М. Шкарапута. К.: Наук. думка, 2000. 680 с.

7. Шевчук С. В., Клименко І. В. Українська мова за професійним спрямуванням: підручник. 5-те вид., виправ. і доп. К.: Алерта, 2019. 640 с.

8. Frank E. X. Dance. The Concept of Communication. Journal of Communicftion, 1970. PP. 201-210.

\section{REFERENCES}

1. Arendt Kh. Vita Activiaor ili o deiatelnoi zhizni (Vita Activia or about an active life). St. Petersburg: Aleteia, 2000. $437 \mathrm{~s}$.

2. Matsko L. I., Matsko O. M. Rytoryka (Rhetoric): navch. posibnyk. Kyiv: Vyshcha shkola, 2003. $311 \mathrm{~s}$.

3. Metodyka vykladannia ukrainskoi movy v serednii shkoli (Methods of teaching the Ukrainian language in high school): navch. posibnyk / za red. I. S. Oliinyka. 2-e vyd., pererob. I dop. Kyiv: Vyshcha shkola, 1989. $439 \mathrm{~s}$. 


\section{ЛІНГВОДИДАТИКА}

4. Natsionalna ramka kvalifikatsii (National qualifications framework) URL: https://zakon.rada.gov.ua/laws/show/1341-2011-\%D0\%BF/paran12\#n12

5. Palykhata E. Ya. Systema navchannia ukrainskoho usnoho dialohichnoho movlennia uchniv osnovnoi shkoly (The system of teaching Ukrainian oral dialogic speech to primary school students): dys. ... dr. ped. nauk: 13.00.02. Kyiv, 2005. $36 \mathrm{~s}$.

6. Slovnyk inshomovnykh sliv (Dictionary of foreign words). Uklad. S. M. Morozov, L. M. Shkaraputa. Kyiv: Nauk. dumka, 2000. $680 \mathrm{~s}$.

7. Shevchuk S. V., Klymenko I. V. Ukrainska mova za profesiinym spriamuvanniam (Ukrainian language for professional purposes): pidruchnyk. 5-te vyd., vyprav. i dop. Kyiv: Alerta, 2014. $640 \mathrm{~s}$.

8. Frank E. X. Dance. The Concept of Communication. Journal of Communicftion, 1970. PP. 201-210. 